\title{
Wpływ koloru przekazu na jego percepcję
}

Kolorystyka jest jednym z podstawowych czynników decydujących o odbiorze reklamy. Nie ulega wątpliwości, że powinna być spójna z prezentowanym produktem lub usługą. Właśnie wybór koloru projektu może przesądzić o sukcesie lub porażce prezentowanych treści. Dlatego tak istotna jest decyzja dotycząca nie tyle samego koloru przekazu, ile również jego odcienia, cienia i tonu. 85\% kupujących deklaruje, że kolor jest podstawowym elementem, który decyduje o wyborze produktu. Dzięki kolorowi rozpoznawalność marki, która bezpośrednio prowadzi do zaufania konsumenta, wzrasta do $80 \%^{2}$. Użytkownik spotykający nowy produkt w pierwszej kolejności 93\% swojej uwagi kieruje na wygląd, 6\% na strukturę i 1\% na zapach/ smak $^{3}$. Dane te potwierdzają zasadność podjęcia analizy wpływu kolorów reklamy na jej odbiór.

${ }^{1}$ http://www.dziennik.com/publicystyka/artykul/kolory-tanczace-w-jazzowych-rytmach (dostęp: 10.09.2017)

${ }^{2}$ https://blog.kissmetrics.com/color-psychology/?wide=1 (dostęp: 10.09.2017).

${ }^{3}$ Ibidem. 


\section{Schematy koła barw i zasady doboru kolorów w projekcie}

Prezentację zagadnienia warto rozpocząć od przedstawienia modelu koła barw (ang. color wheel), które w czytelny sposób obrazuje zasady przenikania się kolorów. Po raz pierwszy opublikował je w 1704 r. Izaak Newton w dziele pt. Optyka, w którym opisał powiązania między kolorami podstawowymi i ich pochodnymi (zob. rysunek 1). Prowadził on doświadczenia rozszczepiania światła białego przez pryzmat, stwierdzając, że za barwę odpowiedzialne jest zjawisko załamania światła. Ponadto zawarł w swej publikacji wyniki badań poświęconych optyce geometrycznej, zjawiskom załamania, dyspersji i odbicia światła, zdefiniował cechy świata białego, polaryzacji, dyfrakcji oraz interferencji światła $w$ warstwach cienkich ${ }^{4}$. Newton wyróżnił siedem czystych kolorów, z których miało składać się heterogeniczne światło - cyfra ta była nawiązaniem do harmonijnego związku siedmiu tonów muzycznej oktawy ${ }^{5}$.

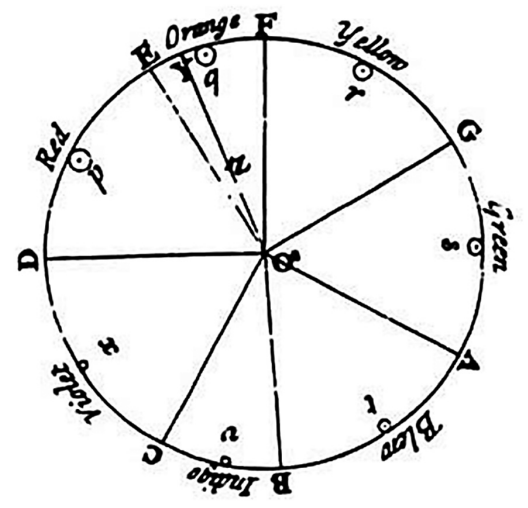

Rysunek 1. Koło kolorów I. Newtona z 1704 r.

Źródło: Newton - 1704, http://historiasztuki.com.pl/NOWA/30-00-01-KOLOR.php (dostęp: 10.09.2017).

Johann Wolfgang von Goethe uważał natomiast, że światło jest homogeniczne. Za kolor prymarny uznawał biel (zainspirowany odbiciami od śniegu) oraz twierdził, że niebieski i żółty to jedyne czyste kolory, które można zaobserwować w naturze, natomiast pozostałe są tylko ich pochodnymi ${ }^{6}$. Badacz uważał, że kolory po przeciwnych stronach koła uzupełniają się („For the colours diametrically opposed to each other in this diagram are those that reciprocally evoke each other in the eye" ${ }^{\text {"7 }}$ ). W swoim modelu opisanym w 1810 r. w publikacji Nauka o barwie (niem. Zur Farbenlehre)

${ }^{4}$ https://encyklopedia.pwn.pl/haslo/Newton-Isaac;3947022.html (dostęp: 10.09.2017).

${ }^{5}$ O. Müller, Goethe i zasady świata barw, autoportret [25-26] 2008-2009, s. 7, http://ingo-nussbaumer.com/pdfs/autoportret.pdf (dostęp: 10.09.2017).

${ }^{6}$ http://historiasztuki.com.pl/NOWA/30-00-01-KOLOR.php (dostęp: 10.09.2017).

${ }^{7}$ J.W. Goethe, Theory of Colours, London 1840, s. 50. 
użył o jeden kolor mniej niż Newton. Była to jednak wyłącznie kwestia umownych podziałów, ponieważ w rzeczywistości koło Goethego roztacza nawet szerszą paletę barw (zob. rysunek 2).

Warto pamiętać, że to właśnie Goethe usytuował w najważniejszym miejscu tarczy, czyli na godzinie dwunastej, swój ulubiony kolor - purpurę $^{8}$. Dodatkowo podkreślał on, że kolory wywołują u odbiorcy reakcje psychologiczne i fizjologiczne, więc nie są dla niego neutralne. Wzbogaciło to dotychczasowe postulaty fizyków, według których widzenie zależało jedynie od parametrów fali świetlnej, z pominięciem psychiki postrzegającego podmiotu. Goethe postulował więc uwzględnianie ciągu przyczynowo-skutkowego „światło-barwa-emocje”"

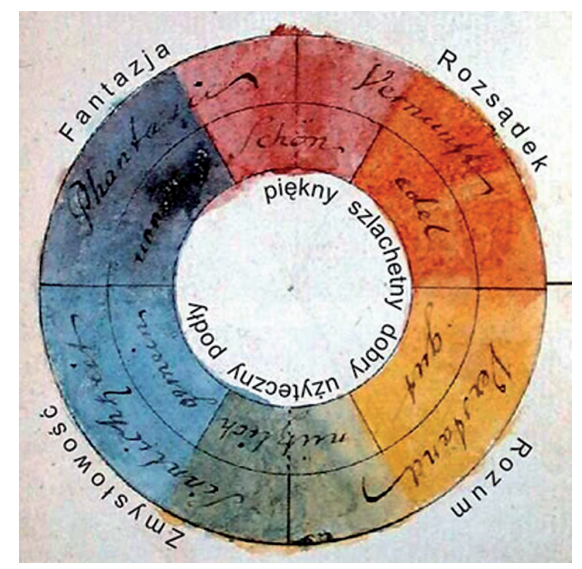

Rysunek 2. Koło kolorów J.W. Goethego z 1810 r.

Źródło: Goethe - 1810, http://historiasztuki.com.pl/NOWA/30-00-01-KOLOR.php (dostęp 10.09.2017).

Można wyróżnić sześć schematów doboru kolorów w projekcie (zob. rysunek 3). Za barwy podstawowe (ang. primary colors) uważa się czerwony, żółty i niebieski. Dlatego też mówi się o modelu kolorów RYB (ang. red, yellow, blue). Przez połączenie dwóch barw podstawowych powstają kolory wtórne, którymi są zielony (niebieski z żółtym), pomarańczowy (żółty z czerwonym) i fioletowy (czerwony z niebieskim). Z kolei dodanie kolorów prymarnych do wtórnych daje następne sześć kolorów wyższych. Kolory analogiczne sąsiadują ze sobą, tworząc spójne kompozycje. Obserwuje się je w warunkach naturalnych w przyrodzie. Modele triadyczne bazują na trzech barwach równomiernie rozlokowanych na kole kolorów i tworzą zróżnicowane kompozycje. Natomiast kolory dzielące - uzupełniające - uzyskuje się poprzez połączenie barwy bazowej $\mathrm{z}$ dwoma uzupełniającymi. To bezpieczne połączenie dające spójne kompozycje.

8 O. Müller, op. cit., s. 7.

${ }^{9}$ P. Zieliński, Między wiedza potoczna a wiedza naukowa - metodologiczne wyzwania w obrębie tak zwanej psychologii barw, Warszawa 2007, s. 3. 
Kolejnym rozwiązaniem projektowym jest schemat prostokąta, wykorzystujący cztery kolory w postaci dwóch uzupełniających się par. W tym wypadku istotne jest zachowanie proporcji między barwami ciepłymi a zimnymi.

Ostatni z wyróżnianych schematów zakłada równomierne rozmieszczenie czterech barw na kole (oddalonych od siebie o $90^{\circ}$ ), tak że między wybranymi rysuje się kwadrat. Podobnie jak w modelu prostokąta, również tu zaleca się wybór jednego koloru dominującego ${ }^{10}$.

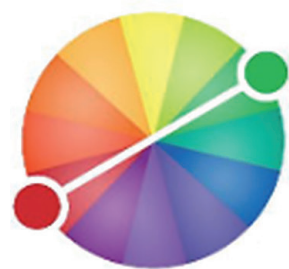

Kolory podstawowe

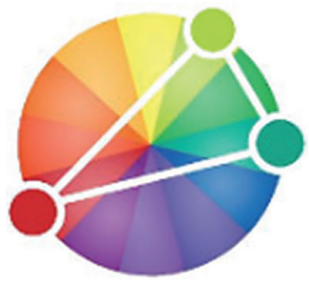

Kolory dzielace - uzupełniające

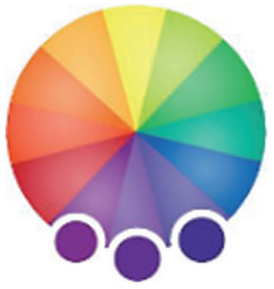

Kolory analogiczne

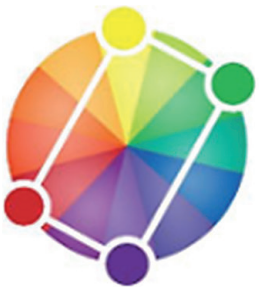

Schemat prostokąta

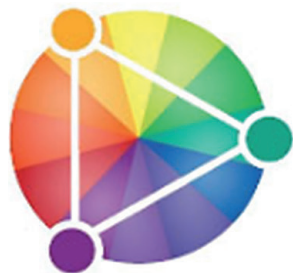

Kolory triadyczne

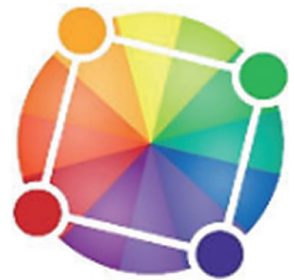

Schemat kwadratu

Rysunek 3. Schematy doboru kolorów w projekcie

Źródło: M. Słowik, Znaczenie kolorów używanych w reklamie. Od teorii barw do psychologii kolorów, https://www. projektowaniegraficzne.pl/znaczenie-kolorow-w-reklamie-teoria-barw-psychologi-kolorow/ (dostęp: 10.09.2017).

\section{Znaczenie poszczególnych kolorów}

Barwy wybierane do strategii promocyjnej produktu mają ogromny wpływ na odczucia odbiorców. Kolorystyka jest bowiem jednym z czynników, które w pierwszej kolejności decydują o skojarzeniach i wyobrażeniach na temat oferty, a docelowo o decyzji zakupowej, która - jak wiadomo - bywa podejmowana nawet w zaledwie

${ }^{10}$ M. Słowik, Znaczenie kolorów używanych $w$ reklamie. Od teorii barw, do psychologii kolorów, https://www.projektowaniegraficzne.pl/znaczenie-kolorow-w-reklamie-teoria-barw-psychologikolorow/ (dostęp: 10.09.2017). 
kilka sekund. Rysunek 4 prezentuje siedem cech, z którymi kojarzą się marki posiadające logo w danych kolorach:

1. żółty - optymizm,

2. pomarańczowy - przyjaźń,

3. czerwony - ekscytacja,

4. fioletowy - mądość,

5. niebieski - zaufanie,

6. zielony - spokój,

7. biały - równowaga.

\section{COLOR EMOTION GLIDE}
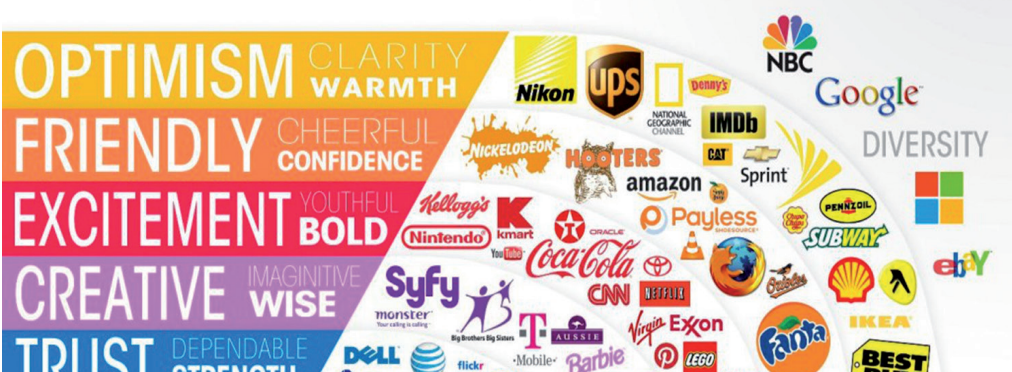

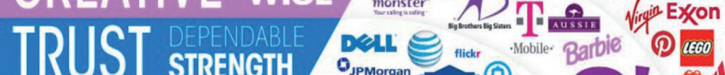
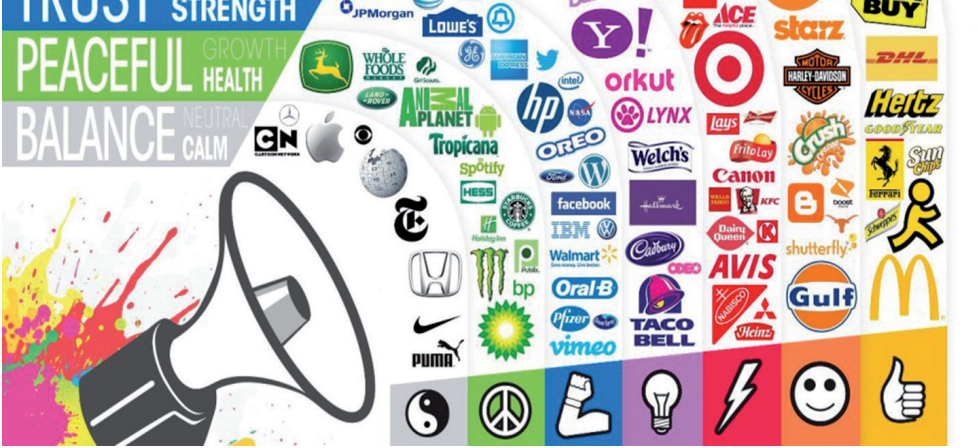

Rysunek 4. Wpływ koloru na odbiór marki

Źródło: A. Białka, Wplyw kolorów na odbiór marki, http://www.fresh.com.pl/blog/wplyw-kolorow-na-odbior-marki/ (dostęp: 10.09.2017).

Planując strategię komunikacji wizualnej, nie można pominąć kontekstu kulturowego, w którym będzie funkcjonowała marka, ponieważ w poszczególnych kręgach kolory bywają sprzecznie interpretowane (o czym dalej: w podrozdziale Różnice kulturowe $w$ konotacji koloru). Na tym etapie warto rozróżnić także mylone często pojęcia, którymi są odcień, cień i ton. Otóż o odcieniu mówi się, kiedy do koloru bazowego dodawana jest barwa biała, dzięki czemu pojawia się kolor jaśniejszy. Na- 
tomiast jeśli do koloru bazowego wprowadza się czerń, w rezultacie powstaje cień (ang. shadow), czyli kolor ciemny, np. ciemna zieleń. Z kolei po dodaniu szarości do koloru bazowego otrzymuje się jego inny ton ${ }^{11}$.

Na podstawie badań psychologicznych i socjologicznych wyodrębniono zespoły cech, które najczęściej kojarzą się z poszczególnymi kolorami (zob. rysunki 5-10). Przykładem badań mogą być prowadzone przez Zofię Kolek pomiary skojarzeń i emocji, jakie wywołuje trzynaście najpopularniejszych barw ${ }^{12}$. W dalszej części pracy przedstawiono charakterystykę wybranych kolorów w oparciu o najpopularniejsze wyniki pojawiające się w doniesieniach naukowych.

\section{Czerwony}

Najczęściej i w najkrótszym czasie skupia uwagę ${ }^{13}$. Kolor krzykliwy, intensywnie emocjonalny, przywołuje skojarzenia z miłością i krwią. Mobilizuje do podejmowania decyzji, wybierany do oznaczania promocji, wyprzedaży i ofert specjalnych. W rzeczywisty sposób może przyczynić się do wzrostu pulsu, ciśnienia krwi i przyspieszenia oddechu (czego dowiodły badania $\mathrm{H}$. Wohlfartha, przeprowadzone na kanadyjskich studentach wpatrujących się w pomalowane plansze $\left.{ }^{14}\right)$.
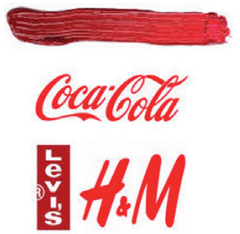

Colgate

Rysunek 5. Znaczenie koloru — czerwony

Źródło: M. Słowik, op. cit.

\section{Pomarańczowy}

Symbolizuje życzliwość i dobroć, kojarzony jest z siłą, witalnością, kreatywnością i entuzjazmem. Odpowiedni dla sektorów rozrywki, zwłaszcza dla młodych grup docelowych (np. Allegro, Orange), nieformalny, niewskazany więc dla komunikacji wizualnej obiektów luksusowych.

11 M. Słowik, op. cit.

12 Z. Kolek, Psychofizyka barwy, „Prace Instytutu Elektrotechniki” 2010, z. 244, s. 10-13.

13 B. Hulten, N. Broweus, M. van Dijk, Marketing sensoryczny, przeł. G. Dąbkowski, Warszawa 2011 , s. 4.

14 http://opiniefall29.republika.pl/piotr+zielinski+metodologia+badan+nad+barwami.shtml (dostęp: 10.09.2017) 


\section{erenose CCC allegro}

Rysunek 6. Znaczenie koloru - pomarańczowy

Źródło: M. Słowik, op. cit.

\section{Żółty}

Dzięki skojarzeniu ze słońcem i radością wykorzystywany często w branży turystycznej i gastronomicznej (np. McDonald’s). Ma być obietnicą szczęścia.

Jeśli chodzi o kolor żółty, w historii reklamy zapisał się Louis Cheskin, który po II wojnie światowej zajął się promocją amerykańskiej margaryny Good Luck. Zamienił kolor opakowania z białego na żółty, a materiał papierowy na folię. Dodał też w rogu znak czterolistnej koniczynki. Prowadził testy na podświadomość, w oparciu o wyniki których zwiększał stopniowo wielkość obrazka aż do momentu, kiedy trójwymiarowa ilustracja liści pokryła całą powierzchnię opakowania. Zanim Cheskin wprowadził modę na margarynę, wcale nie była ona popularna wśród gospodyń domowych. Jej popyt rósł z każdą zmianą opakowania. Odpowiednio dobrane kolory, opakowanie i hasło „to smakuje jak masło" pozwoliły producentowi zdobyć serca konsumentów, a autorowi koncepcji reklamowej trafić do podręczników jako wzór dla późniejszych naśladowców ${ }^{15}$.

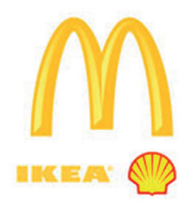

Rysunek 7. Znaczenie koloru — żółty

Źródło: M. Słowik, op. cit.

\section{Zielony}

Budzi skojarzenia ze środowiskiem naturalnym (np. Animal Planet, Greenpeace), ekologicznym stylem życia, produktami owocowo-warzywnymi (Tymbark). Łączony też z tradycją, szlachetnością i finansami (m.in. Credit Agricole, BNP Paribas, BZ WBK) ${ }^{16}$.

15 Z. Bajka, Zarys historii reklamy w Polsce i na świecie, [w:] Zarządzanie reklamą, red. B. Nierenberg, Kraków 2015, s. 32.

${ }^{16}$ M. Więcław, Kolory w marketingu - wybór i znaczenie, http://nowymarketing.pl/a/10148,kolory-w-marketingu-wybor-i-znaczenie (dostęp: 10.09.2017). 


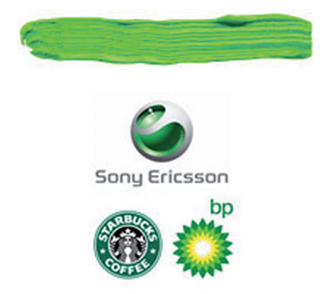

Rysunek 8. Znaczenie koloru — zielony

Źródło: M. Słowik, op. cit.

\section{Niebieski}

Kojarzony z czystością i świeżością, stosowany w marketingu produktów higienicznych, np. past do zębów (np. Oral-B), szamponów (np. Head \& Schoulders) czy kremów (np. Nivea). Budzi zaufanie (m.in. bank PKO BP), daje poczucie przejrzystości, bezpieczeństwa (m.in. PZU), łączony z nowymi technologiami (np. Komputronik, IBM). To barwa stosunkowo uniwersalna, ponieważ jest wybierana zarówno przez mężczyzn, jak i kobiety. Niezalecana jednak do promowania żywności, ponieważ jak dowiodły badania - sprzyja obniżaniu apetytu ${ }^{17}$. Odstępstwem od reguły jest marka spożywcza - Danone. Być może jej kolorystyka ma kojarzyć się z chłodem lodówki.

\section{DANONE}

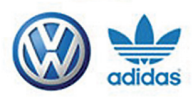

\section{NOKIA}

Rysunek 9. Znaczenie koloru — niebieski

Źródło: M. Słowik, op. cit.

\section{Czarny}

Łączony z luksusem i elegancją, budzi szacunek, może wywoływać silne emocje, kojarzony z siłą, mocą, lecz także ze śmiercią i żałobą. Uważany za barwę uniwersalną, symbol klasyki i stałości kanonów.

\section{Ibidem.}




\section{3
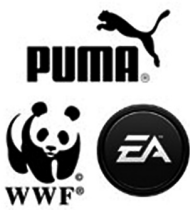 \\ SONY}

Rysunek 10. Znaczenie koloru — czarny

Źródło: M. Słowik, op. cit.

Bywa, że projektant waha się jednak, jakie barwy wybrać. Artur Jabłoński, specjalista od e-marketingu, powiedziałby wówczas: „jeśli nie możesz zdecydować się na nic konkretnego, zrób jak Google"18. Warto więc uważnie przyjrzeć się kreacji marki Google - firmy, która w pierwszym kwartale 2017 r. osiągnęła przychód w wysokości 24,51 mld USD, odnotowując wzrost z 20,09 mld USD (rok do roku) ${ }^{19}$, a jej logo jest jednym $z$ najbardziej rozpoznawalnych znaków na świecie. Mimo że w czasie ewaluowało, ciągle pozostaje w stałej kolorystyce.

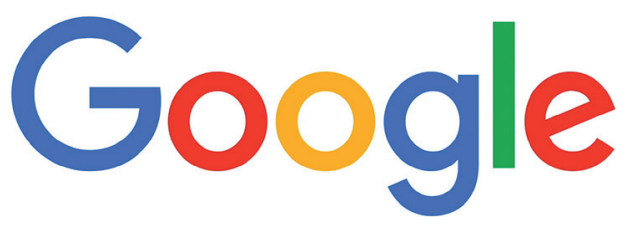

Rysunek 11. Logo Google

Źródło: www.google.com (dostęp: 10.09.2017).

\section{Różnice kulturowe w konotacji koloru}

Wybierając kolory komunikacji wizualnej, zawsze należy uwzględnić kontekst kultury (a niekiedy i symboliki religijnej), w której reklama będzie funkcjonowała. Jak stwierdziła Joanna Tatarska w artykule poświęconym roli koloru w reklamie prasowej:

Oddziaływanie optyczne barw zależne jest od biologii oka i jako takie, w zasadzie identyczne, jest u wszystkich ludzi, jednakże asocjacje i konotacje związane z barwami, ich symboliką oraz reakcje, jakie wywołują w odbiorcach, łączyć należy ze światem wartości ${ }^{20}$.

18 https://arturjablonski.com/kolory-w-reklamie-marketingu/ (dostęp: 10.09.2017).

19 http://www.wirtualnemedia.pl/artykul/alphabet-przychod-i-zysk-google-w-gore-pozostale-marki-zestrata (dostęp: 10.09.2017).

${ }^{20}$ J. Tatarska, Rola koloru w reklamie prasowej, [w:] Reklama wizualna, red. A. Wiśniewska, A. Frontczak, Warszawa 2013, s. 25-26. 
Na przykładzie trzech kolorów: białego, czarnego i czerwonego można wskazać różnice interpretacyjne. Pierwszy z nich w Europie symbolizuje niewinność, czystość i sprawiedliwość. Chrześcijanie łączą go $\mathrm{z}$ wizerunkiem aniołów i świętych. Natomiast Egipcjanie utożsamiali go z pustynią pochłaniającą ludzi, klęską, nieurodzajem i śmiercią. Z kolei Chińczycy wybierają tę barwę na pogrzeby, gdyż symbolizuje nieszczęście i żałobę. Europejczycy takie zastosowanie odnajdują w czerni, kojarząc ją z religijnością i śmiercią. W XX w. zaczęli ją wiązać również z elegancją, szykiem, dobrym, wyrafinowanym gustem. W kulturze chińskiej to barwa małych chłopców, łączona ze szczęściem. Dla Indian i starożytnych Egipcjan wiązała się natomiast z życiodajnym mułem Nilu, więc odczytywali ją jako błogosławieństwo. Z kolei Japończycy utożsamiają biały z niewinnością i młodością, w przeciwieństwie do czarnego - zarezerwowanego dla doświadczenia, wieku i szlachetności (tak samo jak oznaczenia w pasach japońskich sztuk walki). Czerwona barwa w Chinach przyciąga miłość i powodzenie, w tym kolorze suknie wybierają więc panny młode. Również zgodnie z polskimi wierzeniami czerwień przynosi szczęście, dlatego też maturzyści pamiętają o czerwonej bieliźnie, a w tradycji wielkanocnej pisanki pomalowane na ten kolor prowadzą do zwycięstwa i miłości, rozwiązując problemy uczuciowe. Z kolei w południowej Afryce to barwa przelewu krwi, żałoby i złości. W jeszcze innych konotacjach bywa utożsamiana $\mathrm{z}$ rewolucją, komunizmem walką czy powstaniem ${ }^{21}$. $\mathrm{Z}$ tego względu tak istotne jest pamiętanie o funkcjach barw w poszczególnych kulturach, zarówno w wymiarze świeckim, jak i religijnym. Naturalnie można wykorzystać stereotypy do przełamywania w reklamach standardowych skojarzeń czy konwencji, jednak zawsze pamiętając o otoczeniu, dla którego tworzona jest kreacja.

\section{Łączenie kolorów}

Jak mawiał wybitny przedstawiciel romantyzmu, francuski malarz Eugène Delacroix: „kolory są muzyką dla oczu, gdyż dają się zestawiać jak nuty”22. Sformułowanie Delacroix’a stało się nawet hasłem przewodnim internetowego katalogu z trendami $2017 \mathrm{r}$. jednego $\mathrm{z}$ czołowych polskich producentów farb i lakierów ${ }^{23}$. Swobodne, lecz harmonijne połączenie barw może decydować o powodzeniu projektu lub całej strategii marketingowej, a w konsekwencji - wielkości sprzedaży produktu.

Obecnie istnieją narzędzia, za pomocą których można wybrać kolor według odpowiedniego kodu lub klikając punkt na palecie barw. Są to tzw. kalkulatory kolorów (ang.

${ }^{21}$ K. Jurek, Znaczenie symboliczne i funkcje koloru w kulturze, „Kultura - Media - Teologia” 6, 2011, s. 76.

${ }^{22}$ E. Popławska, Kolory tańczące w jazzowych rytmach, http://www.dziennik.com/publicystyka/ artykul/kolory-tanczace-w-jazzowych-rytmach (dostęp: 10.09.2017).

${ }^{23}$ https://www.sniezka.pl/inspiracje/trendy-2017/istota-rzeczy (dostęp: 10.09.2017). 
color calculator). Aby znaleźć pasujące do siebie kolory, wystarczy wybrać jeden z sześciu schematów doboru kolorów w projekcie (por. rysunek 3), a program w formacie RGB, CMYK lub HEX wyświetli pożądane nazwy i zaprezentuje barwy (zob. rysunki 12-13).

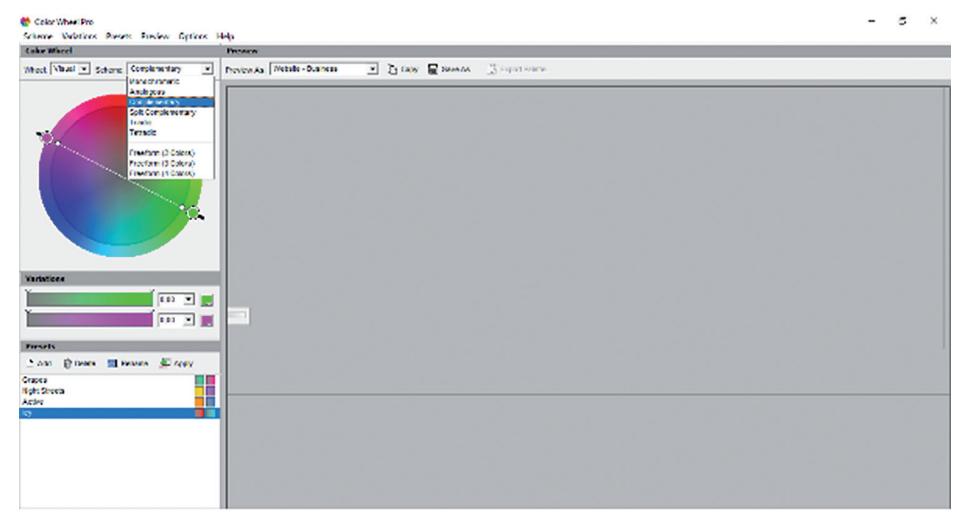

Rysunek 12. Przykład narzędzia - kalkulator kolorów, Color Wheel Pro Źródło: http://www.color-wheel-pro.com/index.html (dostęp: 10.09.2017).

sessionscollege" FOR PROFESSIONML DESIGN then Mapusyro

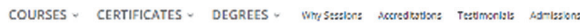

Color Calculator .

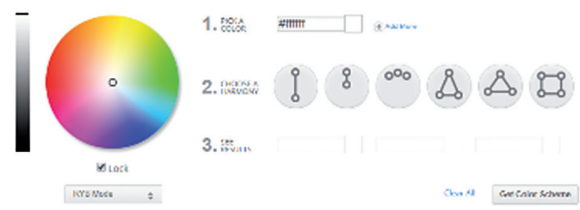

Rysunek 13. Przykład narzędzia — kalkulator kolorów, Sessions

Źródło: https://www.sessions.edu/color-calculator/ (dostęp: 10.09.2017).

CMYK to określenie zestawu czterech podstawowych kolorów w poligrafii i grafice komputerowej, akronim: C - cyjan (ang. cyan), M - magenta (ang. magenta), $\mathrm{Y}-$ zółty (ang. yellow), K - czarny (ang. black lub key colour). Do palety CMY dodano czerń, by nie tracić tuszu aż z trzech pojemników, a do tego otrzymywać prawdziwą barwę. Jeżeli plik ma zostać wykorzystany jedynie w wersji elektronicznej, wystarczy, że będzie stworzony w przestrzeni kolorystycznej RGB (ang. red, green, blue). Z połączenia tych trzech kolorów powstaje biały, z kolei z połączenia składowych CMY uzyskujemy barwę zbliżoną do czerni. Kolory można zapisywać również hexadecymalnie (ang. hex triplet), czyli w postaci sześciu cyfr szesnastkowych 
(tj. trzech bajtów, przypisanych kolejno czerwonemu, zielonemu i niebieskiemu). Dzięki określonym od 0 (00) do FF (255) wartościom znana jest intensywność barwy (od najmniejszej do największej), nazywana kodem HEX.

Decydując o kolorystyce reklamy, należy uwzględnić także, z jakiej odległości będzie ona odbierana i przy jakim oświetleniu, ponieważ te dwie zmienne mogą wpłynąć na jej ostateczny wygląd.

\section{Podsumowanie}

Na podstawie przedstawionych w artykule danych można wyciągnąć wniosek, że kolory wywierają ogromny wpływ na sposób odbioru reklamy przez odbiorcę. Współcześnie przeszkody techniczne pojawiające się podczas projektowania zostały ograniczone do minimum. Istnieje wiele, również bezpłatnych, programów komputerowych do doboru kolorów. Specjaliści zarządzania kolorem (ang. color management) dbają o takie ustawienia urządzeń i oprogramowania, aby otrzymywać prawidłowe, jednakowe reprodukcje obrazów, zarówno na monitorze komputera, w druku cyfrowym, jak i w druku rastrowym ${ }^{24}$. Wyzwaniem ciągle pozostaje określenie grupy docelowej odbiorców reklamy i jej profilu (np. klienci spontaniczni, oszczędni, tradycyjni). Percepcja człowieka w naukach o psychologii koloru i socjologii wizualnej jest coraz częstszym tematem rozpraw, jednak wciąż pozostawia wiele do odkrycia. Nadal liczy się intuicja, gust i wyobrażenie projektanta, lecz dzięki licznym badaniom logotypy, systemy identyfikacji wizualnej i kampanie reklamowe mają szansę stawać się coraz doskonalsze.

\section{An impact of colour of the content on the perception}

Summary

The main idea behind the paper is to find an answer to the question about an impact of colours in advertisements on their reception. This article focused on colour wheel schemes and rules for colour selection in design. Theories of Sir Isaak Newton's and Johann Wolfgang von Goethe's are mentioned here. An important part of the article is Colour emotions guide with particular reference to cultural differences in colour connotations. The last subsection of the paper refers to rules for combining colours.

${ }^{24}$ J. Tatarska, op. cit, s. 34. 